\title{
OPTIMISTIC, DETERMINISTIC DESIGN OF KARAIKAL PORT BREAKWATER STRUCTURE: CASE STUDY
}

\author{
N.R.K.Patnaik ${ }^{1}$, K.Anil Kumar ${ }^{2}$ \\ ${ }^{l}$ Mtech, Civil Engineering Department, Gitam University, Andhrapradesh, India \\ ${ }^{2}$ Assistant professor, Civil Engineering Department, Gitam University, Andhrapradesh, India
}

\begin{abstract}
Ports are important in international trade. These are gateway to country transport for cargo handling and commodity, where vessels may discharge or receive cargo. Karaikal port is the private port between the major ports of Chennai and tuticorin. It has two breakwater one is north breakwater of 650mtr and south breakwater of 600mtr. To increase cargo handling and protection of harbour from the waves and currents, breakwater structure is built and expansion has been taking place 400mtr on North side breakwater and 350mtr on south side Breakwater. For the expansion of breakwater, optimistic and deterministic design has been applied. In the deterministic design structural alternatives have been considered for economic design of breakwater. In the optimistic design we have to consider most economical Concrete Armour unit for the Armour layer of Karaikal port. Design of Rubble mound breakwater in a mathematical model for the purposes of weight of Armour layer and thickness of armour layer has been concluded.Design of Rubble mound breakwater in a mathematical model has consider $x$-bloc as a concrete armour unit which is suitable to reduce Breakwater structure construction cost in a Karaikal port. A breakwater could be optimized with respect to amongst others, construction costs, construction time, material reduction, environmental impacts and total cost. The most promising alternatives should be economically optimized and the results should be compared in order to assess the best solution. Rubble mound breakwater type with an concrete armour unit for that deterministic design and optimistic design has been applied for a Karaikal port.
\end{abstract}

Keywords: Karaikal port 1, Rubble mound break water 2 .

\section{INTRODUCTION}

Disaster is the serious disruption in the functioning of society or community causing human losses or environmental effects. These are natural disaster and manmade disaster, in which natural disaster occurs naturally by the effects of metrological or biological conditions occurred in the nature. Manmade disaster occurs accidently or suddenly. cyclones are occur naturally due to storms and bad weather, these are mainly impacts on port structures such as breakwater structures, seawalls, harbor.

Ports, harbors and marinas are the main examples of coastal structures that people need for efficiently using the coastal areas. These coastal structures usually have defense units named as breakwater in order to protect the area from wave attack. Breakwaters can be constructed as rubble mound, piled, vertical wall or floating according to the wave condition in the coastal area.

Ports are important in international trade. These are gateway to country transport for cargo handling and commodity. It is a place where vessels may discharge or receive cargo.

\section{CYCLONES}

Coastal areas are subjected to damages during storms and cyclones. During severe cyclones the sea water level near shore gets increase because of storm surge. Wind velocities tend to increases incident wave heights. The low-lying coastal areas are thus prone to submergence during such cyclonic storms. Information on the cyclonic storms of the region shall be compiled regarding track of cyclones, the velocity of maximum winds, duration, pressure drop at the cyclone center and speed of movement of cyclone center can obtained from the Indian metrological department (IMD). Cyclones are usually occurred by storms and bad weather. These are mainly impact on ports, structures such as buildings, roads, power, bridges etc due to high velocity winds.

\subsection{Past Cyclones Effected to Port Structures}

In India several cyclones are effect to ports structures, recently HudHud cyclone effect to ports a lot of damage has been occurred to berths and residential quarters in port area, so for protection of port from cyclones, tsunamis, breakwater structure is to be built.

\section{PORTS}

Ports are connecting between sea and land. India has coastline 7517 kilometer across western and Eastern Ghats of the mainland and islands. India has 13 major ports and 200 minor ports, out of 13 major ports, seven are located on west coast and six are located on east coast of the country. $90 \%$ of India's trade by volume and $70 \%$ by value moves through Maritime transport. Maritime transport is a critical infra-structure for development of country. Where vessels may discharge (or) receive cargo. 


\subsection{Significance of Ports}

India trade comprises of export and import trade in various commodities like crude oil, petroleum products, iron-ore and coal etc Total cargo traffic handled by major ports in India during 2014-2015 is 288.48 million tonnes when compared to 2013-2014 it is 277.23 million tones only.

\subsection{Karaikal Port}

Port is located on eastern coast of India in Karaikal district around $300 \mathrm{~km}$ along the south coast of Chennai port and around $360 \mathrm{~km}$ along north coast of Tuticorin port. The Port is situated at latitude of $10^{\circ} 50^{\prime} 56^{\prime}$ ' $\mathrm{N}$ and $10^{\circ} 49^{\prime} 44^{\prime}$ ' $\mathrm{N}$ and Longitude $79^{\circ} 51^{\prime} 8.24^{\prime \prime} \mathrm{E}$ and $79^{\circ} 51^{\prime} 6.40^{\prime \prime} \mathrm{E}$. Karaikal port is deep draft, all weather port. The current depth is 14.5 meter for handling Gearless panamax size vessels. The final depth of $41.5 \mathrm{mtr}$ will allow cape size vessels.

- Extension of northern side breakwater by 400mtr.

- Extension of southern side breakwater by $350 \mathrm{mtr}$.

\subsection{Significance of Karaikal Port}

Ports are gateway to country transport for cargo handling and commodity. Karaikal Ports handled cargos such as coal, raw sugar, cement, construction material and fertilizers. Karaikal port is also hub for oil explorations also.

\section{BOUNDARY CONDITIONS}

Before the Breakwater structure of Karaikal port is to be designed, physical site conditions are to be considered. These conditions determine for layout and design of breakwater at Karaikal port. The boundary conditions for breakwater design include Geotechnical conditions, hydraulic boundary conditions and environmental conditions.

\subsection{Geotechnical Boundary Conditions}

The selection of the type of breakwaters depends up on soil and site conditions. Foundation conditions at site ranges from hard rock to soft mud. It is to measure bottom layer thickness of sea bed and bearing capacity of seabed. Foundation should not be poor to cause settlement Along the alignment. A geotechnical investigation of sea bed is to be required to determine the type of the founding material. To determine what sea bed consists of, eg: hard rock, soft rock, sand, clay, from the results of investigation type of crosssection is to be designed. The Karaikal site has three layers, first layer has coarse dense sand, second layer has loose fine silt sand, and third layer has soft clay.

\subsection{Hydraulic Boundary Conditions}

Every year two monsoons seasons are to be occurred in Bay of Bengal. During the northeast monsoon, cyclones may reach the coast in Karaikal port. From the observations of past years, it appears that the most important treat to breakwater exposed to cyclonic conditions. In this section cyclonic wave height, cyclonic period and directions are to be considered. The effects of water waves are of importance in ocean engineering. Waves are importance in determining geometry and design of harbor.

\subsubsection{Waves}

waves are predominantly from north-east, eastern-northeast, and east during the north east monsoon and south, southern south east, south east, south west, and southern south west during the south west monsoon approach in the port.

\subsubsection{Currents}

The tidal current along Karaikal coast is $0.25 \mathrm{~m} / \mathrm{s}$. The wind driven current due to the wind drift corresponding to a wind speed of $50 \mathrm{mtr} / \mathrm{sec}$ during cyclonic conditions would be 1.5 $\mathrm{mtr} / \mathrm{sec}$.

\subsubsection{Tides}

Tides are rise and fall of sea levels caused by the combined effects of gravitational force exerted by moon, sun and rotation of earth. Tides in these areas are semi diurnal with two high tides and two low tides in a day.

\subsubsection{Wind Speed}

Recording of velocity and direction of wind at the proposed Karaikal site should be obtained by installing continuous and self-recording anemometers.

The data collected should also be correlated with the data available at places nearest to site. From the data so collected, monthly and yearly wind roses should be prepared.

\subsubsection{Wind Data}

Average wind conditions at the Karaikal port

Table 1 wind data

\begin{tabular}{|c|c|c|}
\hline MONTH & DIRECTION & AVG. \\
SPEED KPH
\end{tabular}




\subsection{Environmental Boundary Conditions}

A Breakwater can change in the hydrodynamic conditions. It is essential to undertake environmental impact assessment and hydraulic study during and after the construction of the breakwater for the changes in flow and wave climate. Port activities during construction may impact on groundwater quality. The breakwater constructions lead to contain the seawater within the harbor limits. This is likely to be increase sedimentation of pollutants in the harbor side, which may migrate in time to the neighboring ground water. Also surface water from cargos stacks may percolate as leachets into the ground and may contaminate the ground water in the oceans.

- Tidal flushing and Water quality

- Ecology and Sediment transport

- Siltation and seabed scouring.

\subsection{Karaikal Port Wave Height and Time Data}

\begin{tabular}{|c|c|c|c|c|c|c|c|c|}
\hline & & & & & & & iN & $\mathrm{Ht}$ \\
\hline & TIME & $\mathrm{Ht}$ & & IME & $\mathrm{Ht}$ & & & $\mathrm{m}$ \\
\hline & $\mathrm{hm}$ & $m$ & & $\mathrm{~h} \mathbf{m}$ & $\mathrm{m}$ & & 0251 & 0.09 \\
\hline & 0455 & 0.76 & & 0549 & 0.21 & 21 & 0843 & 0.84 \\
\hline & & 0.23 & 11 & 1152 & 0.72 & & 1442 & 0.04 \\
\hline & 180 & & & 1739 & 0.29 & $w$ & 2112 & 1.03 \\
\hline & & & ! SU & 2355 & 0.82 & & & \\
\hline & 0018 & 0.34 & & 0128 & 0.22 & 2 & $\begin{array}{l}03344 \\
0939\end{array}$ & 06 \\
\hline & O558 & 0.75 & 12 & 1240 & 0.70 & & 1527 & 106 \\
\hline & 1216 & 0.20 & & 1827 & 0.33 & $H$ & 2154 & 04 \\
\hline & 1851 & 0.91 & 4 & & & & & \\
\hline & 011 & 0.29 & & 0037 & 0.77 & & 0421 & 0.05 \\
\hline 3 & 0854 & 076 & 13 & 0710 & 0.23 & 23 & 1021 & 86 \\
\hline & 1301 & 0.17 & & 1337 & 0.68 & & 1613 & 10 \\
\hline & 1934 & 0.93 & $T U$ & 1925 & 0.37 & + & 2237 & 01 \\
\hline & 015 & 0.2 & & 0125 & 0. & & 050 & 0.06 \\
\hline 4 & 0737 & 0.76 & 14 & 0604 & 0.24 & 24 & 11 & 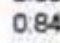 \\
\hline & 1340 & 0.15 & & 1448 & 067 & & 1706 & 16 \\
\hline & $20+2$ & 0.95 & $w$ & 2039 & 040 & SA & 2322 & .96 \\
\hline & 0233 & 0.22 & & 0225 & 0.87 & & 0552 & 0.08 \\
\hline 5 & 0816 & 0.76 & 15 & 0010 & 024 & 25 & 44 & 82 \\
\hline & 1413 & 0.14 & & 1606 & 069 & & 1755 & 12 \\
\hline M & 2045 & 0.95 & TH & 2210 & 0.39 & SU & & \\
\hline & 0305 & 0.2 & & 03 & 0.65 & & 0010 & 0.89 \\
\hline 6 & $0 B 48$ & 0.76 & 16 & 102 & 0.22 & 26 & 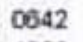 & 0.12 \\
\hline & 1443 & 0.14 & & 1716 & 0.74 & & 1258 & 0.78 \\
\hline ru & 2116 & 0.95 & F & 2331 & 0.34 & $\mathrm{M}$ & 1854 & 0.2 \\
\hline & 033 & 0.20 & & 0 & & & & 1 \\
\hline 7 & 0921 & & 17 & $\begin{array}{l}050 \\
112\end{array}$ & $n \in$ & 27 & 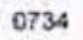 & 16 \\
\hline & 1515 & 0.15 & & $\begin{array}{l}1127 \\
1813\end{array}$ & & & & 74 \\
\hline W & 2145 & 0.94 & SA & & & u & 000 & 0.32 \\
\hline & O. & & & 003 & & & 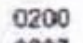 & 0.7 \\
\hline 8 & 0954 & & 18 & $\alpha$ & 0.28 & 28 & $\infty 8$ & 0.2 \\
\hline & 1546 & 0.17 & & 1222 & & & 1518 & 07 \\
\hline $\mathrm{TH}$ & 2213 & 0.02 & su & 1000 & 0.89 & w & 2125 & 0.3 \\
\hline & & & & & & & & \\
\hline 9 & 1031 & & 19 & 07 & 0 & 29 & 0949 & 02 \\
\hline & 1619 & 0 : & & 131 & 0.07 & & 1637 & 0.7 \\
\hline$F$ & 2248 & 0.96 & $M$ & 1945 & $\begin{array}{l}0.07 \\
0.95\end{array}$ & $\mathrm{TH}$ & 2258 & 0.3 \\
\hline & & & & & 0.8 & & 0439 & 0.6 \\
\hline 10 & & & & & 0.14 & 0 & 1104 & 0.2 \\
\hline & 1058 & 0 & 20 & 075 & & & 1746 & 0.7 \\
\hline st & 2318 & 0.66 & TU & $\begin{array}{l}1355 \\
2028\end{array}$ & 0.0 & $F$ & & \\
\hline & & & & & 1.01 & & $\infty$ & 0.2 \\
\hline & & & & & & 3 & & \\
\hline
\end{tabular}

Table 2: Environment report of Karaikal port

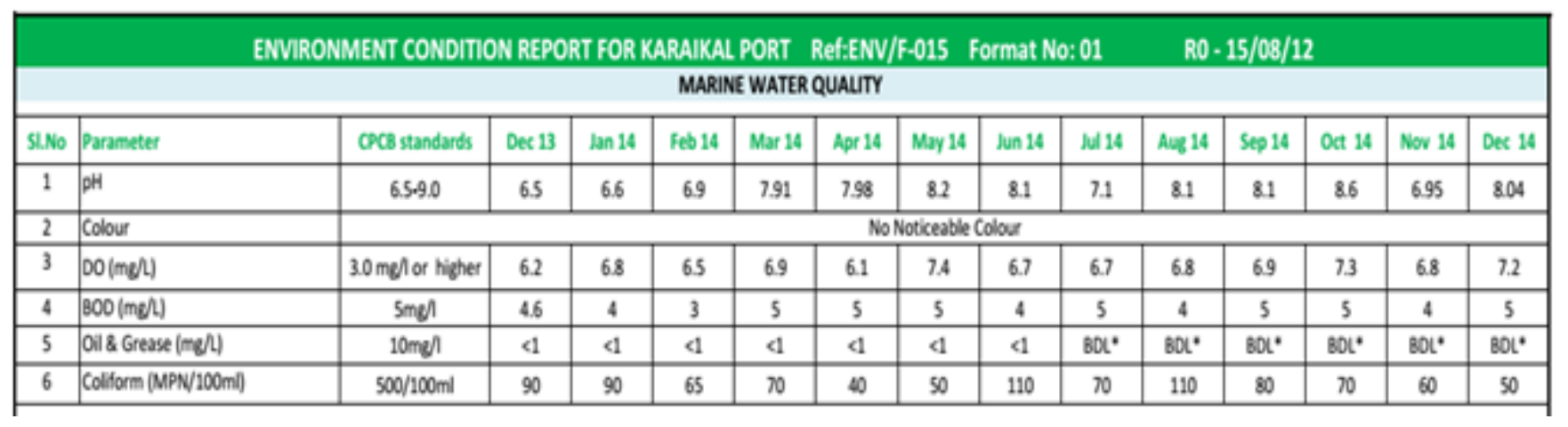


From the Karaikal port wave height and time data the significant wave height caused by typhoons in the Karaikal port follows Gumbel distribution with a mean value of $3.5 \mathrm{~m}$ and a standard deviation of $0.45 \mathrm{~m}$. The wave period is $8 \mathrm{~s}$.

\section{DETERMINISTIC DESIGN}

\section{Breakwater structure}

It is a structure built on seashore to reduce wave action for the purposes of forming artificial harbor with in a basin and quiet water for anchorage and mooring of vessels. They attempt to break incoming waves before reach to shoreline. They are mostly built of quarried rock. Precast armour units such as $\mathrm{x}$ bloc, dolos, tetrapod etc (or) large armour stones are used to protect against wave attack.

\subsection{Structural Alternatives}

(a)Rubble mound break water

(b) Vertical breakwater

(C) Composite breakwater

(c)Submerged breakwater

(d)Detached breakwater

\subsubsection{Rubble Mound Break Water Structure}

These are usually constructed with a core of quarry rock, overlain by one or two layers of bigger rock carefully sized to prevent leaching out of the fines from the core. On the top and sea side of breakwater, concrete armor units (Accropode, tetrapod, and $\mathrm{x}$-bloc) are installed. Concrete crest wall is to be constructed on the top surface of mound to reduce wave overtopping.

\subsubsection{Vertical Breakwater}

A vertical breakwater consists of battered wall section formed by concrete blocks or stones. Now a day's vertical breakwater constructed with concrete caissons filled with sand or concrete. These are constructed to reflect waves without dissipating energy. Vertical breakwater requires less material, less space and less construction time.

\subsubsection{Composite Breakwater}

A Vertical structure is placed on top of a rubble mound and it acts as a composite breakwater. Composite breakwater structure serves as rubble mound breakwater during low tides and vertical breakwater during high tides.

\subsubsection{Submerged Breakwater}

Submerged Breakwaters are also called as low-crested breakwater made up of concrete or rock elements are constructed to reduce wave energy, reducing of wave energy is not high. It is difficult to construct in sea environment and posses navigation risk in marine environment.

\subsubsection{Detached Breakwater}

A Detached breakwater are non-shore connected but near shore breakwater reducing the beach erosion. They are constructed parallel to the shoreline in a shallow water depth. Multiple detached breakwaters are also built parallel to shoreline can provide protection to shoreline.

$>$ Considering the experience of construction of breakwater and ability of construction equipments and other aspects Rubble breakwater type was chosen in Karaikal port construction.

\subsection{Rubble Mound Breakwater}

Rubble mound breakwaters are structures constructed of quarry rock and protected by concrete armour units.Recent development in rubble mound breakwater depends on using shape designed concrete blocks. Rubble mound breakwaters are most economical structures built at site with limited water depth. The typical cross section of the rubble mound breakwater includes core made up of stones and rocks weighing between $20 \mathrm{kgs}$ and $300 \mathrm{kgs}$ and secondary armour layer made up of armour layer of quarry rock with a weight of 1 ton and primary armour layer made of $\mathrm{x}$-bloc and the $\mathrm{x}-$ bloc weight is 7.0tons.

\subsection{Failure Modes of Breakwater}

\subsubsection{Introduction}

A Distinction can occur between the total failure of structure, ultimate limit state or the situation when the structure does not full fill functions, serviceability limit state, eg. More downtime in harbor basin and a gap occurs between the failure of total breakwater and failure of individual units.

\subsubsection{Failure Modes}

Failure can be defined as exceedence of a predefined limit state, occurs when the load exceeds the strength. When this exceedence occurs failure of structure can be defined. Failure occurs both during construction and after construction of Breakwater structure.

A Breakwater consists of several parts, which occurs individually failure of the whole breakwater.

$>$ Failure of Armour layer

$>$ Failure of toe construction

$>$ Failure of inner slope of breakwater

$>$ Failure of subsoil

\subsection{General Failure Modes In A Breakwater}

Collapse of the Breakwater

$>$ Excessive wave height in the basin

$>$ Obstruction of the entrance channel

\subsubsection{Collapse of the Breakwater}

Collapse of the breakwater occurs to the Ultimate limit state (ULS).As a result of structure collapse, the protective function of the breakwater will be lost. In this study, it is assumed that port operations are active during normal conditions. Whenever storm comes port stops its operation and ships have to leave the berths. 


\section{Ultimate Limit State of the Breakwater}

The breakwater consists of many parts, Concrete armour units, concrete cap, toe structure. Collapse of one of these parts will weaken the resistance of other parts, eventually the whole structure fails. Ultimate limit state failure occurs under extreme conditions.

\subsubsection{In Excessive Wave Height Inside the Harbor \\ Basin During Normal Weather Condition}

The port operations at the lee sides can only be carried out with a maximum wave height in the harbor. Whenever wave height exceeds the maximum allowable height, Breakwater system can be considered to be fail. The failure mechanism occurs without collapse and can be regarded as a serviceability limit state (SLS).

\section{Serviceability Limit State of the Breakwaters}

During normal conditions Breakwater system can be considered to fail if the wave height inside the basin exceeds maximally allowable wave height.

\subsubsection{Obstruction of Entrance Channel}

Obstruction of entrance channel can be occur due to bad Breakwater layout. A ship runs around navigation channel will cause traffic obstruction and affect the port operations.

\section{RUBBLE MOUND BREAKWATER BY A MATHEMATICAL MODEL DESIGN PROCEDURE}

\subsection{Weight of Armour Units}

The Hudson formula developed for concrete armour, unit was derived from results of wave test for concrete armour stability conditions. When the crest of the structure is high enough to prevent major overtopping. The formula has been widely used. The formula does not take account of many factors such as wave period and angle of incident wave, shape, type and interlocking of armour units, method of placing armour units and crest elevation relative to wave height. The formula should not be used for a low crest structure.

\subsection{Design Parameters}

Table 3: Design parameters

\begin{tabular}{|l|l|c|}
\hline $\begin{array}{l}\text { Deep Water Significant } \\
\text { Wave Height }\end{array}$ & Hs0 $(\mathrm{m})$ & 3.8 \\
\hline Significant Wave Period & Ts $(\mathrm{sec})$ & 8 \\
\hline Structure Face Slope & $\cot (\alpha)$ & 2 \\
\hline $\begin{array}{l}\text { Unit Weight of Armour } \\
\text { Stone }\end{array}$ & $\gamma$ stone $(\mathrm{t} / \mathrm{m} 3)$ & 2.7 \\
\hline Unit Weight of Sea Water & $\gamma$ water $(\mathrm{t} / \mathrm{m} 3)$ & 1.02 \\
\hline Unit Weight of Armour unit & $\mathrm{Y}(\mathrm{N} / \mathrm{m} 3)$ & 24 \\
\hline
\end{tabular}

Weight of X-bloc Armour layer

A widely used formula for the design of concrete armour units is Hudson's formula

$$
W_{50}=\frac{\gamma_{a} H^{3}}{K_{D}(S G-1)^{3} \cot \alpha}
$$

Where $\mathrm{W}$ is design weight of armour

$Y_{r}$ is specific weight of the armour block

$\mathrm{H}$ is design wave height

$\mathrm{K}_{\mathrm{D}}$ is dimensionless stabilitycoefficient

$\mathrm{SG}=\left(\rho_{\mathrm{r}} / \rho_{\mathrm{w}}-1\right)$

$\mathrm{P}_{\mathrm{r}}$ is density of the concrete armour unit

$\mathrm{P}_{\mathrm{w}}$ is density of water

$\alpha$ is angle.

Table 4: kd values

\begin{tabular}{|l|c|c|c|c|}
\hline s.no & \multicolumn{2}{|c|}{$\begin{array}{l}\text { Trunk } \\
\text { section of } \\
\text { breakwater }\end{array}$} & \multicolumn{2}{l|}{$\begin{array}{l}\text { Head } \\
\text { section of } \\
\text { breakwater }\end{array}$} \\
\hline & Breaking & $\begin{array}{c}\text { Non- } \\
\text { breaking }\end{array}$ & Breaking & $\begin{array}{c}\text { Non- } \\
\text { breaking }\end{array}$ \\
\hline $\begin{array}{l}\mathrm{X}- \\
\text { bloc }\end{array}$ & 16 & 16 & 13 & 13 \\
\hline
\end{tabular}

$\mathrm{W}=\left(2.4 *(5)^{3}\right) /\left((13)(2.4 / 1.025-1)^{3} * 1.33\right)$

$\mathrm{W}=7.18 \mathrm{t}$.

Weight of $\mathrm{x}$-bloc is $7.18 \mathrm{t}$.

\subsection{Thickness of The Armour Layer}

The thickness of the Armour unit can be calculated from the below equation

$$
r=n K_{\Delta}\left(\frac{W}{\gamma_{a}}\right)^{1 / 3}
$$

Where $W_{a=}$ Weight of individual armour unit $(\mathrm{N})$.

$n=$ Number of Armour layers.

$k_{\Delta}=$ Layer thickness coefficient.

$\gamma_{a}=$ Unit weight of the armour unit $\left(\mathrm{N} / \mathrm{m}^{3}\right)$.

$$
\begin{aligned}
\mathrm{r} & =2 * 1.49 *(5.84 / 2.4)^{1 / 3} \\
& =3.98 \mathrm{~m} .
\end{aligned}
$$

The average number of armour units per unit area $N_{a}$ may be determined by the formula

$$
N_{a}=n k_{\Delta}\left(1-\frac{p}{100}\right)\left(\frac{\gamma_{a}}{W_{a}}\right)^{2 / 3}
$$

Where $p=$ Volumetric porosity.

$\mathrm{N}_{\mathrm{a}}=2 * 1.49 *(1-61 / 100) *(24 / 7.18)^{.2 / 3}$

$\mathrm{N}_{\mathrm{a}}=2.71$ stones $/ \mathrm{m}^{2}$. 


\subsection{Design of Armour Stone (DAS)}

Design Armour Stone (DAS) is the second part that calculates armour stone weight using Hudson formula.

$\mathrm{H}=0.78 * 3.8=2.96 \mathrm{~m}$.

$$
W_{50}=\frac{\gamma_{a} H^{3}}{K_{D}(S G-1)^{3} \cot \alpha}
$$

$\mathrm{W}=2.65 * 2.96^{3} /\left(3.5(2.65 / 1.025-1)^{3} * 2\right.$

$\mathrm{W}=2.65^{*} 2.96^{3} /\left(3.5(2.58-1)^{3} * 2\right)$

$\mathrm{W}=68.71 /(27.61)$

$\mathrm{W}=2.48 \mathrm{t}$.

The thickness of the underlayer $t_{u}$ should be contain at least two layers of rock and may be determined from the following formula:

$$
t_{u}=n k_{\Delta}\left(\frac{W}{\gamma_{r}}\right)^{1 / 3}
$$

Where $\mathrm{W}=$ Weight of a rock in the underlayer $(\mathrm{N})$.

$\mathrm{n}=$ Number of rock layers.

$\mathrm{k}_{\Delta}=$ Layer thickness coefficient, equal to 1.15 for rock.

$\mathrm{T}=2 * 1.15(2.48 / 2.65)^{1 / 3}$

$=2.25 \mathrm{~m}$.

$$
\text { (A) } \begin{aligned}
\mathrm{D} 50 & =(\mathrm{W} / \mathrm{Yr})^{1 / 3} & \text { (B) } \mathrm{D} 15 & =0.40 * \mathrm{D} 50 \\
& =(2.48 / 2.65){ }^{1 / 3} & & =0.40 * .97 \\
& =0.97 \mathrm{~m} & & =0.39 \mathrm{~m} .
\end{aligned}
$$

\section{Secondary layer}

$\mathrm{W} 50=$ Warmour $/ 10=2.48 / 10=0.248 \mathrm{t}$.

$\mathrm{T}=2 * 1.15^{*}(.248 / 2.65)^{1 / 3}=1.104 \mathrm{~m}$.

$$
\begin{aligned}
& \begin{array}{ll}
\text { (A) } \mathrm{D} 50=(0.248 / 2.65)^{1 / 3} & \text { (B) } \mathrm{D} 85=1.96 * \mathrm{D} 50
\end{array} \\
& =0.45 \mathrm{~m} \\
& =0.89 \mathrm{~m} \text {. }
\end{aligned}
$$

Check $=(\mathrm{D} 15)$ Armour $/(\mathrm{D} 85)$ Armour

$$
\begin{aligned}
& =0.39 / 0.89 \\
& =0.43 \leq 5 \quad \text { ok }
\end{aligned}
$$

\subsection{Crest Width}

The crest elevation should be determined from wave run-up and overtopping considerations.

$$
B=3 k_{\Delta}\left(\frac{W_{a}}{\gamma_{a}}\right)^{1 / 3}
$$

Where, $\mathrm{W}_{\mathrm{a}}=$ Weight of an individual armour unit $(\mathrm{N})$.

$k_{\Delta}=$ Layer thickness coefficient.

$\gamma_{a}=$ Unit weight of armour unit $\left(\mathrm{N} / \mathrm{m}^{3}\right)$.
$\mathrm{B}=3 * 1.15^{*}(2.48 / 24)^{1 / 3}$

$\mathrm{B}=1.62 \mathrm{~m}$.

\section{ECONOMIC OPTIMISATION}

\subsection{Introduction}

An economic optimal design is defined as design for which the total lifetime costs are minimal with some design constraint. The total cost is defined as the cost of construction plus anticipated damage and economic loss due to failure of structure.

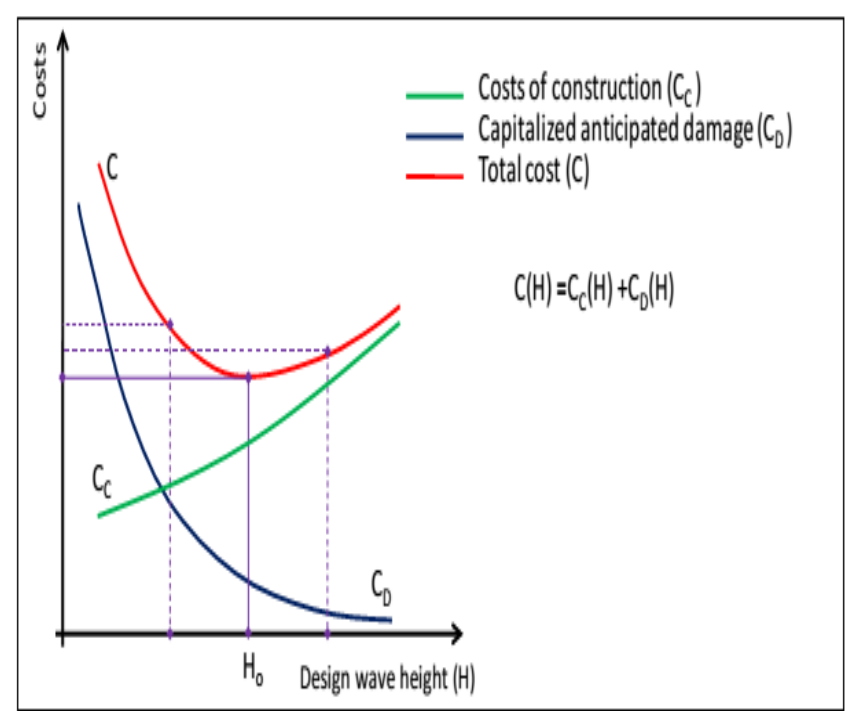

Fig 5: Total cost as a function of design wave height

When designing a structure has to be established and the respective design wave should be determined. Design wave is a probability value and there is always probability of value to be exceeded. An increase in design wave value will lead to rise on construction cost.

\subsection{Construction Cost}

The construction cost can be assessed by designing crosssection that occurs in the functional requirements for different design wave heights $(\mathrm{H})$. After completion of designing cross-section by means of deterministic approach the material volume per meter of breakwater have to calculated and used to compute material cost. A Fixed value for mobilization and others have to be considered.

\subsection{Optimisation Procedure}

During a designing process several structural alternatives can be generated. Within one structural concept a number of alternative structural geometries may be possible. Fully optimization of structural design is likely to be trail and error method with many iteration circle and a large number of boundary conditions.

To decide whether geometry is applicable in one structural concept, acceptable value of the failure probability should be prescribed. 
Full probabilistic economic optimization of Breakwater structure

In the previous approach, cross-section design for each design wave height is obtained by deterministic design calculation and only failure mode considered is the armour layer instability.

Table 5: structure of optimization process

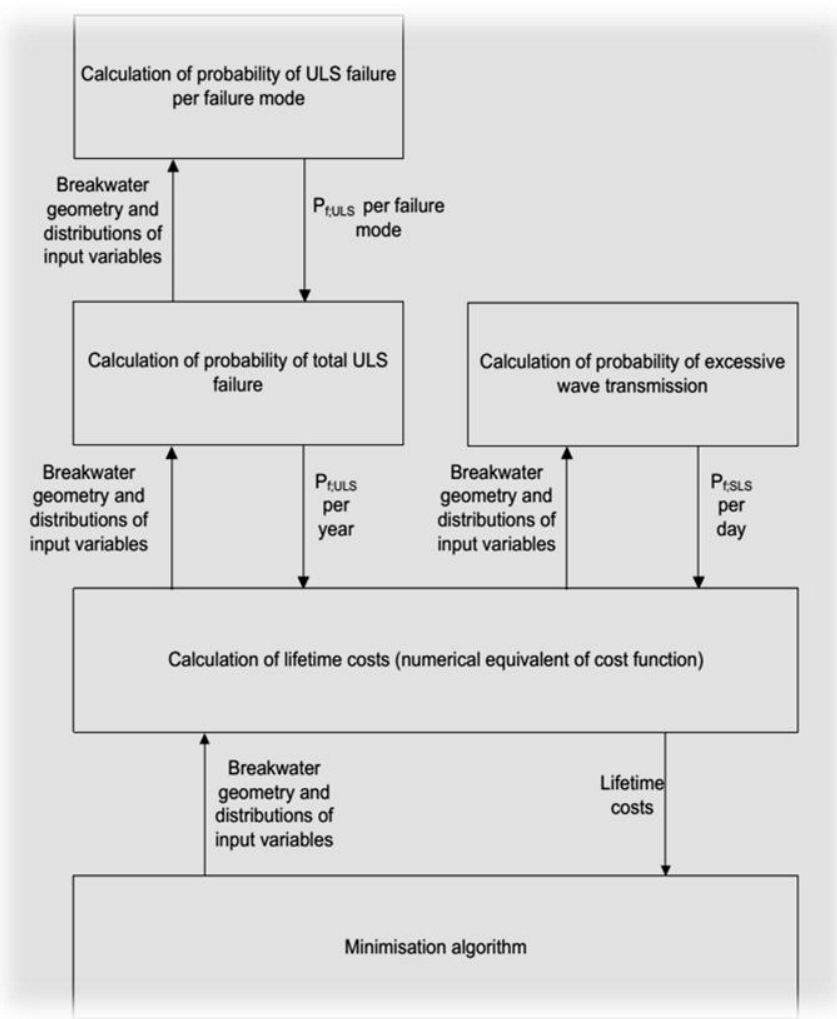

In the full probabilistic economic optimization, other design variables crest height, water depth at the toe and others can be optimised.

\subsection{Numerical Result}

Optimization is carried out for the weight of concrete armour unit and crest height of the breakwater. Assumes that the height of wave wall is fixed, crest height in the low profile determines the wave transmission as well as the wave overtopping during extreme conditions.

Table 6: Estimated cost of failure

\begin{tabular}{|l|l|c|}
\hline \multicolumn{1}{|c|}{ ITEM } & \multicolumn{1}{|c|}{ DESCRIPTION } & US \$ \\
\hline \multicolumn{2}{|l|}{ Cost of collapse of Breakwater Due to extreme event } \\
\hline \multicolumn{2}{|l|}{ Structural damage } \\
\hline $\begin{array}{l}\text { Damage to } \\
\text { breakwater }\end{array}$ & $\begin{array}{l}\text { 20\% of } \\
\text { construction cost }\end{array}$ & $20 \% \mathrm{I}_{\mathrm{CON}}$ \\
\hline $\begin{array}{l}\text { Damage to other } \\
\text { structures in port }\end{array}$ & $\begin{array}{l}\text { Harbor lights, } \\
\text { store house etc }\end{array}$ & 300,000 \\
\hline $\begin{array}{l}\text { Mobilization of } \\
\text { contractor }\end{array}$ & Estimate & 100,000 \\
\hline Sub total & & $\begin{array}{l}400,000 \\
20 \% \text { Icons }\end{array}$ \\
\hline
\end{tabular}

\begin{tabular}{|c|c|c|}
\hline \multicolumn{2}{|l|}{ Economic damage } & \multirow[b]{2}{*}{$55 \times 10^{6}$} \\
\hline $\begin{array}{l}\text { Alternative } \\
\text { transportation of } \\
\text { goods }\end{array}$ & $\begin{array}{l}\text { throughput } 30 \\
\text { mil ton/year, cut } \\
\text { off } \\
50 \% \text { in } 1 \text { year, } \\
\text { extra cost US \$ } 5 \\
\text { / ton: }\end{array}$ & \\
\hline $\begin{array}{l}\text { Cost of shipping } \\
\text { operation }\end{array}$ & $\begin{array}{l}\text { Average } 1 \\
\text { vessel/day }\end{array}$ & 512,500 \\
\hline $\begin{array}{l}\text { Loss of direct } \\
\text { income }\end{array}$ & $\begin{array}{l}\text { throughput } 30 \\
\text { mil ton/year; port } \\
\text { dues } \\
\text { US \$ } 5 \text { / ton }\end{array}$ & $55 \times 10^{6}$ \\
\hline $\begin{array}{l}\text { Loss of indirect } \\
\text { income }\end{array}$ & $\begin{array}{l}\text { bad reputation, } \\
\text { shipping lines, } \\
\text { other } \\
\text { parties }\end{array}$ & $40 \times 10^{6}$ \\
\hline subtotal & & $\begin{array}{r}150.512 \times \\
10^{6}\end{array}$ \\
\hline $\begin{array}{l}\text { Total structural and } \\
\text { economic damage }\end{array}$ & & $\begin{array}{r}150.91 \times 10^{6} \\
+20 \% \text { Icons }\end{array}$ \\
\hline
\end{tabular}

The weight of concrete armour units decides the hydraulic stability of the primary Armour layer. The design constraints are the allowable values of wave height in port basin overtopping discharge and the stability numbers of armour layers and toe. While a smaller x-bloc Armour layer can withstand severe typhoons, the higher crest considerably reduces the wave overtopping and wave transmission. The port downtime decreases and results in a better economic efficiency in a long life time.

\section{CONCLUSION}

1. As the prediction of Natural Calamities is not possible, some extent it can be prevented by safety Breakwater Construction.

2. Application of economic optimisation with probabilistic analysis to the conceptual design of a rubble mound breakwater has been demonstrated and proves to be a rational way to achieve an optimal geometry alternative.

3. In this study, the x-bloc weight and the crest level were optimised by balancing the investment costs with the reduction failure risk. Other design variables can also be optimised following the same approach.

4. Simulation studies are well conducted for cost assessment.

5. For the design and maintenance procedure comparative study is conducted.

\section{REFERENCES}

[1] Gavin N palmer, Colin D Christian 1998 " Design and construction of rubble mound breakwater" IPENZ Transactions, volume 2.

[2] Ghassan Elchahal, Rafic Younes, Pascal Lafon 2013” Optimization of coastal structure s: Application on detached breakwater $\mathrm{s}$ in ports" Ocean Engineering 63. 
[3] W.H. Tutuarima, K.d.Angremond, "Cost comparison of Breakwater types 1988" Published by coastal engineering.

[4] Orson P. Smith, "cost effectiveness of breakwater cross section 1987" ASCE Journal of Waterway, Published by Port, Coastal, and Ocean Engineering, Vol. 113, No. 5.

[5] Jentsje W,van der Meer 1988 "deterministic probalistic design of breakwater armour layer" J. Waterway, Port, Coastal, Ocean Eng. Volume 114.

[6] Julien De Rouck, "Geotechnical design of breakwater in Ostend on very soft soil" Published by Port, Coastal, and Ocean Engineering.

\section{BIOGRAPHIES}

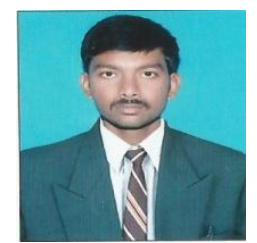

N.R.K.Patnaik resident of Andhrapradesh received his bachelors degree in civil engineering from vitam college of engineering, He has worked with gkc projects ltd, and presently he is Master student in structural engineering \& natural disaster management in Gitam university.

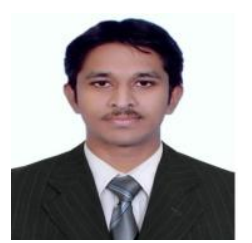

Katta.Anil Kumar (assistant professor) resident of Andhrapradesh received his mtech (structural engineering) from Acharya Nagarjuna University. he has also worked as design engineer in viswa vani engineers and presently he is assistant professor in Gitam university. 